\title{
The effectivity of ozone water application on tampon in post posterior tooth extraction in Department of Oral Surgery and Maxillofacial Faculty of Dentistry, University of North Sumatera (USU)
}

\author{
Hendry Rusdy, ${ }^{*}$ Abdullah Oes, Indra B. Siregar, David Sitompul
}

\begin{abstract}
Objective: Tooth extraction in oral surgery can lead to bleeding. Ozone water is a material that is able to accelerate healing process and prevent socket inflammation by stimulating and speeding up the work of cells like fibroblasts. Moreover, ozone water quickens the release of oxygen to the tissue to kill microorganism in tooth socket and accelerate healing process.

Material and Methods: This is experimental research using post-test only with control group design. Ozone water is made using DSM Aero High Voltage. The ozonation process takes 30 minutes and followed by soaking a tampon in the ozone water. Patients in the treatment group bite the tampon for 30 minutes while patients in the control group bite a dry tampon. After 30 minutes, the tooth socket is checked
\end{abstract}

to observe the inflammation using the Gingival Score Index. Patients are instructed to come back 7 days after the tooth extraction to check on the inflammation. There is a total of 38 samples in the study and they are divided into 2 groups (treatment and control). This study is conducted in the Department of Oral Surgery and Maxillofacial Faculty of Dentistry USU.

Results: The average of Gingival Index after 30 minutes is $0.42 \pm 0.507$ and $0.95 \pm 0.911$ for treatment and control groups, respectively. On day 7 the average is $0.00 \pm 0.00$ for treatment group and $0.37 \pm 0.496$ for control group.

Conclusion: Ozone water is able to stimulate and quicken the healing process for wounds and reduce the inflammation of the tooth socket.
Department of Oral Surgery and Maxillofacial, Faculty of Dentistry, University of North Sumatera, Medan, Indonesia
*Corresponding to: Hendry Rusdy, Department of Oral Surgery and Maxillofacial, Faculty of Dentistry, University of North Sumatera, Medan, Indonesia hendry.rusdy@usu.ac.id

Received: 20 August 2018 Revised: 10 ctober 2018 Accepted: 7 November 2018 Available Online 1 December 2018

Keyword: Ozone water, Gingival index, Socket inflammation

Cite this Article: Rusdy H, Oes A, Siregar IB, Sitompul D. 2018. The effectivity of ozone water application on tampon in post posterior tooth extraction in Department of Oral Surgery and Maxillofacial Faculty of Dentistry, University of North Sumatera (USU). Journal of Dentomaxillofacial Science 3(3): 177-179. D0l: 10.15562/jdmfs.v3i3.793

\section{Introduction}

Tooth extraction causes wounds while it is done to prevent any tissue damages due to pathology or trauma. ${ }^{1}$ Tooth loss is more common in females than males. ${ }^{2}$ Wounds are caused by damages of skin structures and functions due to pathology process that comes from intrinsic and extrinsic factors related to the organ. Several wounds can lead to complications like haemorrhage. Under normal conditions, haemorrhage is treated by haemostasis as a response from the body to stop the large blood flow. Wounds healing methods consist of components with stimulation characteristics that are able to heal wounds in several phases like haemostasis, inflammation, proliferation and remodelling. ${ }^{3}$ A study by Alpana et al. ${ }^{4}$ found that ozone water can speed up the epithelization and stimulate the fibroblast to speed up wound healing. Metabolism activity from cell fibroblast reached the highest concentration when induced by ozone water rather than $2.5 \%$ of $\mathrm{NaOCl}$. Moreover, ozone water is able to stimulate odontoblast cells to fight lipopolysac-charide produced by the bacteria.

Ozone is a gas compound that consists of 3 oxygen atoms such as singlet oxygen $\left(\mathrm{O}_{1}\right)$ and oxygen $\left(\mathrm{O}_{2}\right){ }^{5}$ Singlet oxygen is very reactive especially at foreign substance in the body like bacteria, virus and other parasites.

Ozone easily dissolves in water, is a strong oxidant, is colourless and has a distinct smell. Ozone effectively kills foreign substances like microbes in the body and has the ability to break cell walls of bacteria and to inhibit bacterial activities in the body.

Ozone water has got the effect as a disinfectant, sterilization, haemostasis agent and to accelerate wound healing by increasing oxygen content and increase oxygen metabolism in the tissue.

Based on the background described, it is essential to study about the effectivness of ozone water tampon application in post posterior tooth extraction in the Department of Oral Surgery Faculty of Dentistry USU. 


\section{Material and Methods}

This study is an experimental research using posttest only with control group design. Samples were collected using purposive sampling. A total of 38 samples were divided into two groups, treatment and control. The research was done in the Department of Oral Surgery and Maxillofacial in Faculty of Dentistry USU.

Samples were selected using inclusion and exclusion criteria. They were also given an explanatory page from the researcher. Tooth extraction was performed by students in the clinic and the researcher prepared a tampon soaked in ozone water prior to beginning treatment. The researcher also prepared dried tampons for control group. After tooth extraction was completed, an ozone soaked tampon was given to the treatment group and dry tampon was given to the control group. Each group bit the tampon for 30 minutes.

After 30 minutes, the tooth socket of the two groups was observed using the Gingival Score Index. Research subjects were instructed to disturb the extraction area with their tongue or chew food

\section{Table 1 Sample distribution}

\begin{tabular}{lcc}
\hline Group & Total (\#) & Percentage (\%) \\
\hline Treatment & 19 & 50 \\
Control & 19 & 50 \\
Total & 38 & 100 \\
\hline
\end{tabular}

Table 2 The distribution of Gingival Index in every group at 30 minutes and 7 days of post extraction

\begin{tabular}{lcccc}
\hline Gingival & \multicolumn{2}{c}{ Treatment } & \multicolumn{2}{c}{ Control } \\
\cline { 2 - 5 } Index Score & $\begin{array}{c}\mathbf{3 0} \text { mins post } \\
\text { extraction }\end{array}$ & Day-7 & $\begin{array}{c}\mathbf{3 0} \text { mins post } \\
\text { extraction }\end{array}$ & Day-7 \\
\hline Light (0-1) & 19 people & 19 people & 12 people & 19 people \\
Medium (2) & 0 & 0 & 7 people & 0 \\
Heavy (3) & 0 & 0 & 0 & 0 \\
\hline
\end{tabular}

Table 3 The average of Gingival Index of every group observed at 30 minutes post extraction

\begin{tabular}{lcc}
\hline Group & Mean \pm SD & p-value \\
\hline Treatment & $0.42 \pm 0.507$ & $0.034^{*}$ \\
Control & $0.95 \pm 0.911$ & \\
\hline
\end{tabular}

Table 4 The average of Gingival Index of every group observed in day-7 post extraction

\begin{tabular}{lll} 
Group & Mean \pm SD & P-value \\
\hline Treatment & $0.00 \pm 0.000$ & \\
Control & $0.37 \pm 0.496$ & $0.003^{*}$ \\
\hline
\end{tabular}

from the extraction side. Samples were requested to check on the socket healing on Day-7 after extraction.

\section{Results}

A total of 38 samples were divided into two groups, a treatment group and a control group consist of 19 samples each table 1 .

The distribution of gingival index in each group is summarized in table 2 . The results 30 minutes after extraction showed that 19 samples in the treatment group had a light gingival Index score (0-1). For control group, there were 12 samples with a light gingival index score (0-1) and 7 samples with a medium gingival index score (2).

The average score of gingival index for treatment group was $0.42 \pm 0.507$ and $0.95 \pm 0.911$ for the control group 30 minutes after extraction. pvalue in the table shows the significance of the result. p-value obtained is 0.034 (where pvalue $<0.05$ shows a meaningful difference, table 3 .

The average gingival score in the treatment group was $0.00 \pm 0.00$ while control group had an average of $0.37 \pm 0.4967$ days after tooth extraction. $\mathrm{P}$-value gives a significant difference where the value obtained is 0.003 table 4 .

\section{Discussion}

Haemorrhage is a process of blood flowing from blood vessel with due to wall damage in blood vessels that is caused by trauma or diseases. Haemostasis is a self-defence mechanism with the important role of stopping excessive bleeding. There are 4 phases in haemostasis and they are vasoconstriction, platelet aggregation, adhesion, and blood coagulation.

Based on the results above, there is a significant difference between treatment group (given a tampon soaked in ozone water) and control group (given a dried tampon) who are observed 30 minutes and 7 days after the tooth extraction. Naturally, the body will give a clear reaction to lesion. The first event will be an acute inflammation. If the body fails to do the normal process, then chronic inflammation will take place. ${ }^{6}$

Inflammation phase happens on day 2 to day 4 , when fibroblast and leukocyte cells enter tooth socket to kill the bacteria around the socket and to form clots on top of tissue to cover the wounds., ${ }^{2,3}$ The use of ozone water in the medical field has several functions such as to kill bacteria and virus, to heal infection, as a disinfectant, stimulate and quicken the release of oxygen in the tissue to speed up healing process. ${ }^{7-9}$ According to Kumar et al. ${ }^{10}$ ozone water changes and stimulates the flexibility and elasticity of erythrocytes directly. Consequently, 
the blood flow rate increases and quickens oxygen transport to the tooth socket. ${ }^{10}$

Ozone works in erythrocytes by increasing the production of 2.3 DPG (2.3 diphosphoglycerate) enzyme. ${ }^{11,12}$ The enzyme works to stimulate the growth and production of new blood cells which releases oxygen into the tissue. The increase of this enzyme will break the bonds between haemoglobin $(\mathrm{Hb})$ and oxygen $\left(\mathrm{O}_{2}\right)$ which enhances oxygen transport into the tissue and therefore speed up healing process in the socket.

This mechanism also increase proliferation of fibroblast that rises collagen deposition and forms fibronectin through revascularization process. Specifically, ozone water increases the release rate of fibroblast and epithelization as ozone water is able to increase the metabolism of L-929 fibroblast cells and it will reach the highest level when induced by ozone water. This mechanism leads to the speeding up of socket healing with pseudomembrane formed on top of socket which protects socket from either mechanical or physical trauma.

Besides working to stimulate the release of fibroblast cell, ozone water is also effective to kill microorganism like bacteria, virus and other parasites in the tissues in the body. Singles oxygen $\left(\mathrm{O}_{1}\right)$ is one of ozone molecules with reactive properties especially with foreign substances in the body. The mechanism is to break the cell walls of bacteria. This causes nucleic acid bonds, carbon and nitrogen chain in the bacteria to break. As a result, the bacteria will not be able to produce energy for metabolic processes.

When the tissue has enough blood flow around it, then oxygen flow enters the tissue faster to promote the production of collagen. The collagen formed will support new vascularization around tooth socket to fasten healing process and prevent hypoxia to occur around socket.

\section{Conclusion}

Ozone water has the effect to stimulate and quicken healing process for wounds and reduce the inflammation of tooth socket.

\section{Acknowledgment}

The authors state no funding to declare.

\section{Conflict of Interest}

The authors report no conflict of interest.

\section{References}

1. Hupp JR, Ellis E, Tucker MR. Contemporary oral and maxillofacial surgery. 4thed. Missouri: Elsevier; 2003. p. 95.

2. Montandon AAB, Zuza EP, de-Toledo BEC. Prevalence and reasons for tooth loss in a sample from a dental clinic in Brazil. Int J Dent 2012;20: 1-2.

3. Guo S, DiPietro LA. Factors affecting wound healing. J Dent Res 2010;89: 219-229.

4. Talukdar A, Langthasa M, Barman I. Ozone therapy: Boon to dentistry and medicine. Int J Pre Clin Dent Res 2015;2: 59-66.

5. Kristanti Y, Desy. Pengaruh ozonated watersebagai antiseptik dalam menghambat pertumbuhan staphilococcus aureus. Maj Kedok Gigi 2012;19: 25-28.

6. Velnar T, Bailey T, Smrkolj V. The wound healing process: An overview of the cellular and molecular mechanisms. J Int Med Res 2009;37: 1528-1542.

7. Tiwari S, Avinash A, Katiyar S. Dental applications of ozone therapy: A review of literature. Saudi J Dent Res 2016;6: 105-109.

8. Sari NN, Sururi MR, Pharmawati K. Efek perlakuan pH pada ozonisasi. J Institut Teknol Nasional 2013;1: 1-11.

9. Kumar A, Bhagawati S, Tyagi P. Current interpretations and scientific rationale of the ozone usage in dentistry: a systematic review of literature. Eur J General Dent 2014;3: 175-179.

10. Sujatha B, Kumar M, Gowd P. Ozone therapy: a paradigm shift in dentistry. Health Sci 2013;2: 1-6.

11. Al-Aziz AA, Eweda SM, Kholosy HM. Effect of ozone therapy dressing technique on the healing process of recent 2 nddegree burns. IOSR-JNHS 2015;4: 26-49.

12. Zhao JH, Tsai CH, Chang YC. Clinical and histological evaluations of healing in an extraction socket filled with platelet-rich fibrin. J Dent Sciences 2011;6: 116-122.

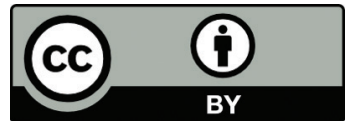

This work is licensed under a Creative Commons Attribution 